REVITALISASI KAWASAN BENTENG KOLONIAL DI

WILAYAH KEPULAUAN MALUKU SEBAGAI BAGIAN

PENGEMBANGAN RENCANA TATA RUANG WILAYAH

(Sebuah Gagasan Konseptual)

\title{
Wuri Handoko
}

Balai Arkeologi Ambon

Kementerian Kebudayaan dan Pariwisata

Jl. Namalatu-Latuhalat 97118 Ambon

Hp. 081341132503, Email: wurhand@yahoo.co.id

\section{Abstrak}

Di Wilayah Kepulauan Maluku, meliputi Propinsi Maluku dan Maluku Utara, merupakan wilayah yang kaya akan potensi kawasan benteng kolonial yang sesungguhnya dapat menudukung pembangunan. Namun kondisi kekinian yang ada sekarang membutuhkan adanya program revitalisasi yang efektif dan efisien. Program revitalisasi kawasan perlu mempertimbangkan tahapan penilaian dan pengkategorian kawasan yang menghasilkan urutan prioritas kawasan dengan kriteria skala prioritas. Program revitalisasi kawasan benteng juga dimaksudkan menjadi bagian dari pengembangan rencana tata ruang wilayah dan kota, sehingga program revitalisasi mendukung pembangunan wilayah dan kota.

Kata kunci : revitalisasi, penilaian, kawasan, prioritas, rencana tata ruang wilayah

\section{Abstract}

The Moluccas islands which is included The Moluccas and Northern Moluccas Province, is a rich region of the forts complex potential that might be used to support the development. Hence, the recent condition may needs an effective and efficient revitalization program. However, the implementation of this idea still needs to consider the assessment and categorization of the region that will result the priority scale of particular area. This revitalization program was also meant to be the part of the regional development spatial planning so it might effectively serves to support the development of the urban area

Keywords: revitalization, assessment, region, priority, regional development spatial planning. 


\section{Latar Belakang}

Pusat Dokumentasi Arsitektur (PDA) mencatat hanya lima persen dari 257 benteng peninggalan masa kolonial di Indonesia, yang masih dalam kondisi utuh. Mayoritas kondisi benteng-benteng tersebut tinggal sisa dan reruntuhannya saja. Kerusakan benteng-benteng peninggalan masa kolonial lebih banyak disebabkan oleh pembiaran yang dilakukan pemerintah, maupun masyarakat di sekitarnya. Indonesia bisa belajar dari India yang mampu merestorasi serta mengkonservasi benteng masa kolonial untuk kemudian dimanfaatkan secara ekonomis. Untuk sementara tim peneliti yang terdiri dari Passchier Architects and Consultants (PAC), Pusat Dokumentasi Arsitektur Indonesia (PDA), serta Dirjen Sejarah Dan Purbakala Departemen Kebudayaan Dan Pariwisata, merekomendasikan formulasi kebijakan untuk pelestarian dan pengembangan benteng sebagai benda cagar budaya yang dilindungi; pelestarian fisik (pemugaran, konservasi, revitalisasi) dan pemanfaatan benteng. (www.pda-id.og).

Pertanyaan pentingnya adalah bagaimana kita bisa mengumpulkan energi untuk bisa melalukan hal itu? Lantas, bagaimana kita bisa menghadirkan sesuatu untuk tampil dan dapat dilihat kembali secara utuh, jika sosok dan bahan bakunya sendiri sesungguhnya sebagian besar telah musnah. Pertanyaan terakhir yang terpenting adalah, seberapa besar manfaat yang dapat dipetik dalam progam restorasi dan konservasi itu sendiri, sebab tentu kita juga harus berhitung, seberapa besar cost yang kita harus keluarkan dengan hasil yang akan tercapai.

Pertanyaan tersebut sesungguhnya berdasar pada kondisi riil di lapangan, dimana benteng-benteng kolonial itu berada. Pengalaman penulis mendampingi tim surveyor dari PDA, dapat dengan langsung melihat kondisi riil di lapangan benteng-benteng kolonial khususnya di wilayah Propinsi Maluku. Kondisi riil yang dimaksud adalah kondisi saat ini baik fisik maupun sosial dengan lingkungan sekitar benteng. Sesungguhnya penulis ingin katakan, kita perlu memilih dan memilah dengan cermat, mempertimbangkan dengan bijak manfaat dan kerugiannya, serta merencanakan dengan matang serta menerapkan konsep pengelolaan dengan tepat. Sebagai contoh, hampir tidak mungkin kita melakukan restorasi, atau rehabilitasi atau revitalisasi, pada kondisi benteng yang hampir-hampir tidak berbekas lagi, menyisakan puingpuing berserak ditengah-tengah kepungan pemukiman permanen milik warga. Sementara kita tidak semestinya membiarkan begitu saja benteng kolonial, hanya karena masih tampak utuh. Sebaliknya jangan merehabilitasi benteng kolonial, jika justru merusak keaslian dan menciderai nilai kesejarahannya.

Di Wilayah Kepulauan Maluku sendiri, hasil pendataan PDA menyebutkan jumlah Benteng dan bangunan kolonial lainnya di Propinsi Maluku sejumlah 67 buah dan di Maluku Utara tercatat sebanyak 49 buah benteng belum termasuk pertahanan yang biasanya dalam bentuk palbox yang tersebar di sepanjang pantai dan gunung. Dari sekian banya benteng yang terdata, baru sebagian kecil saja, yang terdaftar sebagai Benda Cagar Budaya (BCB). Artinya, dari sekian banyak benteng kolonial yang terdata, hanya sebagian kecil saja yang sudah dikelola. Masalah pengelolaannyapun juga masih belum tuntas dibicarakan dan diperdebatkan oleh karena berbagai kepentingan belum diperoleh titik temu.

Makalah singkat ini berupaya menawarkan gagasan konseptua bagaimana mengelola Benteng-benteng kolonial di wilayah Propinsi Maluku dan Maluku Utara di tengah menyeruaknya banyak masalah lain yang mengikut dalam pengelolaan benteng yang tengah berlangsung saat ini. Mula-mula, perlu dilakukannya pengidentifikasian kawasan yang banyak berdiri bangunan kolonial baik dalam kategori kawasan utama yang paling prioritas maupun kawasan lain baik kota maupun pedesaan yang dapat menjadi bahan pertimbangan dalam skala prioritas revitalisasi bangunan kolonial dalam skala kawasan yang lebih luas, antara lain berkaitan dengan pengembangan rencana tata ruang wilayah dan kota.

\section{Penilaian Kawasan Benteng Kolonial dan Skala Prioritas Program Revitalisasi}

Keberadaan suatu bangunan kuno bersejarah mencerminkan kisah sejarah, tata cara hidup, budaya dan peradaban masyarakatnya. Budihardjo (1989) mengatakan bahwa terdapat beberapa arti penting dari keberadaan suatu bangunan kuno bersejarah antara lain secara ekonomis, bangunan

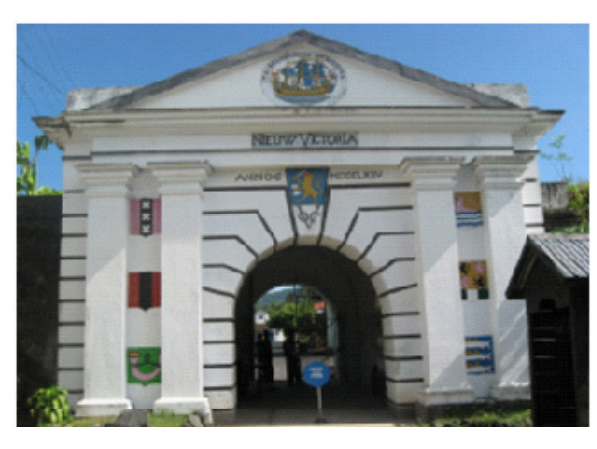

Kapata Arkeologi Vol 7 Nomor 13 /Noverber 2011 


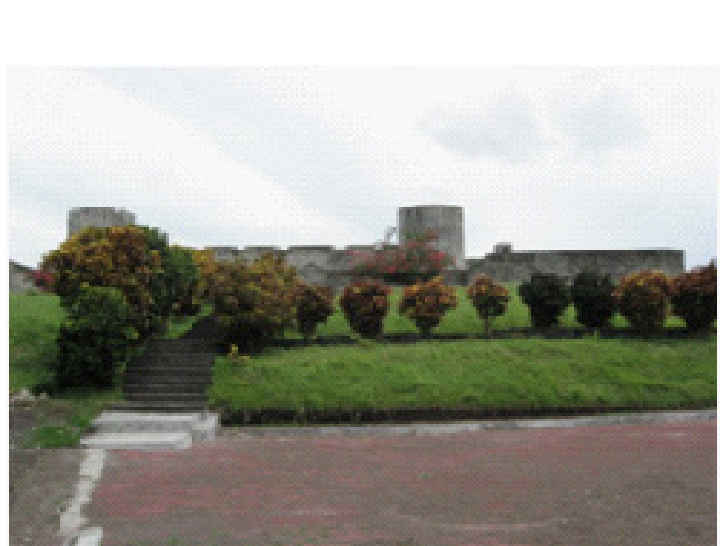

Benteng Belgica, Ikon utama Kota Kolonial Banda Neira yang tampak masih utuh dan menjadi obyek wisata budaya di Banda Neira.

Sumber Foto: PDA dan Balai Arkeologi Ambon (2007)

kuno bersejarah akan merupakan salah satu daya tarik wisata dari aspek sosial budaya terpeliharanya bangunan kuno akan menumbuhkan ikatan yang erat antara masa kini dan masa lampau dan menciptakan kebanggaan serta harga diri sebagai bangsa, dan menurut aspek fisik bahwa keberadaan bangunan kuno bersejarah akan memperkaya wajah lingkungan dan menciptakan identitas kota yang khas, unik dan berkarakter. Kawasan bersejarah (cagar budaya) yang tidak tertata dengan baik dikhawatirkan nantinya akan semakin buruk kondisinya apabila tidak dilakukan penangangan yang serius. Kondisi yang demikian juga merupakan ancaman serius bagi kota secara tidak langsung karena dapat mempercepat penurunan kualitas fungsional, visual, maupun lingkungan. Salah satu upaya perbaikan lingkungan adalah revitalisasi kawasan. Upaya tersebut harus dilakukan secara terpadu dan melibatkan semua aspek yang terkait, baik yang sifatnya fisik dan non fisik maupun para aktor pelakunya (Effendi, 2001; Indrawaty, 2008).

Di wilayah Kepulauauan Maluku, Benteng Kolonial tersebar pada hampir seluruh wilayah. Deretan benteng-benteng Kolonial tersebut bisa mewakili adanya kawasan-kawasan yang pada masa kolonial merupakan kawasan konsentrasi pertahanan Kolonial. Masa Kolonial, daerah itu merupakan kawasan kota sebagai pusat pemerintahan kolonial. Deretan benteng di kawasan kota menjadi penanda bahwa kawasan itu merupakan daerah strategis yang harus dikuasai dan dipertahankan oleh pihak Kolonial. Di Wilayah Maluku dapat disebut beberapa kawasan kota Kolonial, yang hingga sekarang dapat diidentifikasi spesifikasinya. Di Pulau Ambon, selain di Kota Ambon sendiri, jazirah Leihitu di bagian utara Pulau Ambon juga dapat disebut kawasan Kota kolonial. Kawasan ini ditandai oleh banyaknya benteng-benteng kolonial. Di Kota Ambon, selain Benteng New Victoria, terdapat Benteng Middlesborgh, di daerah Passo, selebihnya di dominasi oleh bunker-bunker Jepang. Sementara itu di Jazirah Leihitu, masih di Pulau Ambon hingga saat ini masih bisa disaksikan deretan benteng-benteng Kolonial di beberapa lokasi. Di Desa Hila, terdapat Benteng Amsterdam yang masih utuh, serta deretan benteng lainnya yang berdiri pada hampir setiap negeri atau desa di Jazirah Leihitu. Di Banda Neira, bisa mewakili Kota Kolonial, yang hampir seluruh kota menggambarkan wajah kota Kolonial, oleh karena deretan benteng dan bangunan kolonial pada hampir seluruh area kota. Banda Neira, bahkan dianggap sebagai kawasan utama kota Kolonial, oleh karena hingga sekarang berbagai bentuk aristektur kolonial masih bertahan.

Penilaian kawasan Benteng Kolonial di Wilayah Kepulauan Maluku, dapat disejajarkan dan didasarkan oleh kondisi pencitraan kawasan Kolonial seperti yang dijelaskan oleh Dewi dan Surjono (2008) dalam memberi pencitraan kawasan kota lama Semarang, berikut ini :

a. Jaringan jalan (path) adalah jaringan pergerakan berupa jalur tempat manusia akan bergerak dari suatu tempat ke tempat lain.

b. Kawasan (district) merupakan integrasi dari berbagai kegiatan fungsional atau bentuk bangunan yang memiliki keseragaman, yang membedakan dengan kawasan lain.

c. Batas (edge) merupakan suatu pengakhiran dari suatu district/ kawasan. Batas (edge) kawasan Kota kolonial yang dapat diidentifikasikan dengan adanya deretan deretan bangunan peninggalan Belanda yang berarsitektur kolonial.

d. Landmark) merupakan suatu struktur fisik yang paling menonjol di antara struktur kota atau suatu bagian wilayah kota dan akan menjadi perhatian utama dibandingkan dengan elemen fisik lainnya.

Di wilayah Maluku citra kawasan Kolonial, secara menonjol tampak sekali di kawasan Banda Neira, selian itu juga di Pulau Ambon (Kota Ambon dan Jazirah Leihitu), Haruku dan Saparua, juga dapat diamati integrasi bangunan kolonial dalam satu kawasan, batas-batas maupun landmark. Citra kawasan kolonial yang ditunjukkan oleh jaringan jalan, terutama paling tampak adalah di kawasan kota Ambon dan Banda Neira. 
Penilaian terhadap

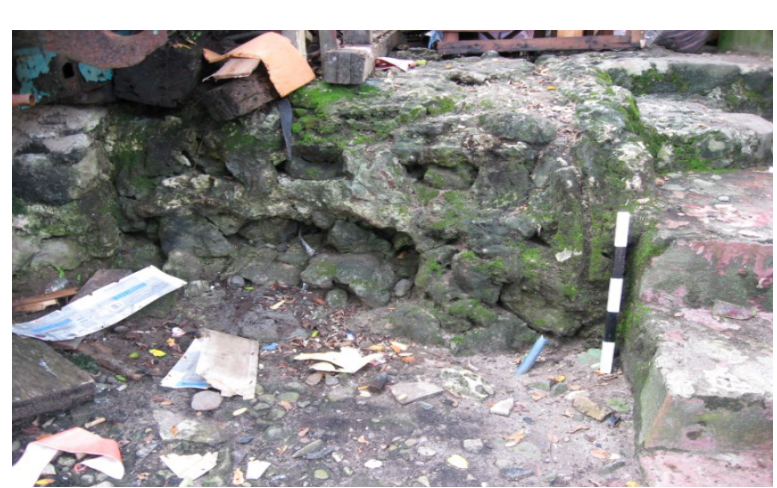

kawasan bentengbenteng kolonial, mengingat kondisi perkembangan kawasan yang diakibatkan oleh gejala penurunan kualitas lingkungan maupun dinamika Kondisi kekinian Blokhuis Leiden saat perkembangan sosial ini, yang tinggal menyisakan puing-puing budaya di kawasan bekas pondasi benteng. Gambar diambil tersebut. Serageldin (2000) menjelaskan, gejala penurunan kualitas fisik dapat

dengan mudah diamati pada kawasan kota bersejarah, karena sebagai bagian dari perjalanan sejarah (pusat kegiatan perekonomian dan sosial budaya), kawasan kota tersebut umumnya berada dalam tekanan pembangunan (Serageldin et al,2000). Tingkat penurunan kualitas lingkungan dan fisik kawasan benteng kolonial di Kepulauan Maluku dapat menjadi pertimbangan dalam kerangka perencanaan program revitalisasi. Hal ini agar pelaksanaan $\begin{array}{llllllll}p & \mathrm{r} & \mathrm{o} & \mathrm{g} & \mathrm{r} & \mathrm{a} & \mathrm{m}\end{array}$ dapat berjalan seimbang antara teknispelaksanaan, hasil yang tercapai dan kondisi kekinian kawasan.

Berdasarkan hal tersebut, maka penilaian kawasan benteng kolonial di wilayah Maluku akan menghasilkan pengategorian

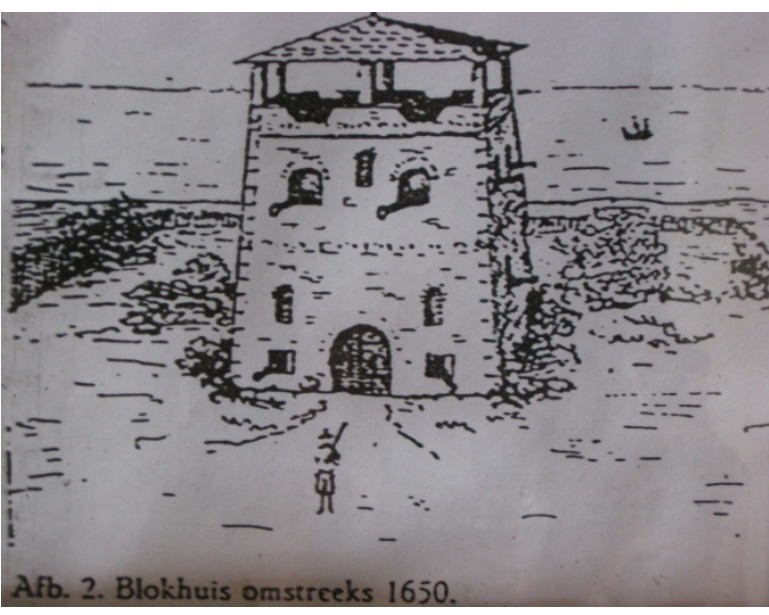

Gambar Blokkhuis Leiden, kondisi tahun 1650. Sumber: PDA (2007) kawasan kolonial berdasarkan peringkat atau perangkingan kawasan yang berdasarkan pada kondisi citra kawasan yang masih ada. Oleh karena itu masih perlu diidentifikasi lebih lanjut lagi hasil survey bangunan Kolonial di wilayah Kepulauan Maluku untuk mengidentifikasi kategori-kategori citra kawasan kolonial, mengingat kondisi saat ini yang sebagian besar tidak utuh lagi. Mansyur (2008) merangkum hasil survey bangunan kolonial di wlayah Propinsi Maluku dalam kategori masih utuh, hampir musnah dan musnah (selengkapnya lihat Mansyur, 2008:597-601).

Pelestarian adalah upaya pegelolaan pusaka melalui kegiatan penelitian, perencanaan perlindungan, pemeliharaan, pemanfaatan, pengawasan,dan/atau pengembagan secara selektif untuk menjaga kesinambungan, keserasian, dan daya dukungnya dalam menjawab dinamika jaman untuk membangun kehidupan bangsa yang berkualitas (Piagam Pelestarian Pusaka Indonesia 2003). Area konservasi adalah area yang memiliki karakteristik khas pada arsitektural dan nilai sejarahnya yang berpotensi untuk dilestarikan. Karakter yang khas tersebut meliputi topografi area, perkembangan sejarah, penggunaan material untuk membangun, dan kualitas keterhubungan area tersebut dengan bangunan, alam, dan open space (Ross, 1991: 120-121 dalam Eriza 2009).

Penilaian dan penentuan kawasan benteng kolonial di beberapa wilayah kota di Propinsi Maluku dan Maluku Utara adalah suatu alat yang paling efektif digunakan untuk melindungi struktur kawasan dari pembangunan bangunan baru. Menurut Katrinka Ebbe (1999) struktur kawasan adalah pola penggunaan lahan dan jaringan jalan, keragaman langgam arsitektur, dan aktifitas kehidupan masyarakatnya. Ketiga hal inilah yang akan memberikan penduduk kota suatu sense of place dan identitas (Ebbe, 1999 dalam Kwanda, 2001). Dengan pertimbangan itu maka perlu dibuat urutan skala prioritas revitalisasi benteng kolonial. Selain penilaian dan pengkategorian kawasan seperti yang telah dijelaskan diatas, juga perlu dilakukan kriteria penentuan skala prioritas program revitalisasi. Beberapa kriteria untuk menentukan skala prioritas yang dapat ditawarkan dalam program revitalisasi Benteng Kolonial di wilayah Maluku sebagai berikut :

- Kriteria kemendesakan: dalam kriteria ini lebih difokuskan terutama pada obyek-obyek yang keberadaannya benar-benar terancam dan mengandung nilai penting yang sangat tinggi terhadap sejarah dan budaya. 
- Kriteria akar Masalah/Kebutuhan, kriteria ini mensyaratkan pada hubungan sebab akibat sehingga pembangunan yang dilaksanakan dapat memenuhi kebutuhan di sektor lainya. Dalam pembahasan ini, kriteria ini mensyaratkan agar revitalisasi benteng kolonial bertujuan menjawab permasalahan di sekitarnya.

- Kriteria Kepentingan Publik, pembangunan yang dilaksanakan benar-benar mampu memenuhi kebutuhan publik baik secara sosial maupun ekonomi, artinya pembangunan yang dilakukan benar-benar membawa kemanfaatan bagi masyarakat terutama yang bermukim di sekitar kawasan benteng Kolonial.

- Kriteria Ketersediaan Potensi, potensi dan sumber daya yang ada dapat mendukung kebutuhan pembangunan, sebab bertendensi pada efisiensi. Sebagai contoh mungkin lebih prioritas merehabilitasi Benteng Kolonial yang masih tampak utuh dan lebih dekat dengan kawasan yang berkembang dibandingkan merehabilitasi benteng kolonial yang tingga puing-puing dan di wilayah padat penduduk serta kondisi kawasan yang statis.

- Kriteria menambah pendapatan, dalam kriteria ini hasil pembangunannya dapat dimanfaatkan untuk memperoleh pendapatan pemerintah maupun meningkatkan kesejahteraan masyarakat.

- Kriteria Keberlanjutan. Kriteria keberlanjutan (jangka panjang), artinya pendanaan yang dikeluarkan menghasilkan dampak yang berkelanjutan sehinga tidak perlu melakukan pemborosan biaya pembangunan untuk kebutuhan yang sama. (lihat juga Handoko, 2008).

\section{Revitalisasi Kawasan Benteng dan Pengembangan Rencana Tata} Ruang Wilayah

Dalam Rancangan Peraturan Presiden Tentang Rencana Tata Ruang (RTR) Kepulauan Maluku Bab I bagian I poin 12 menyangkut pengertian tentang Kawasan Cagar Budaya adalah tempat serta ruang di sekitar bangunan bernilai budaya tinggi, situs purbakala dan kawasan dengan bentukan geologi tertentu yang mempunyai manfaat tinggi untuk pengembangan ilmu pengetahuan. Selanjutnya pada Bagian Ketiga menyangkut Strategi Perwujudan Pola Pemanfaatan Ruang, Paragraf

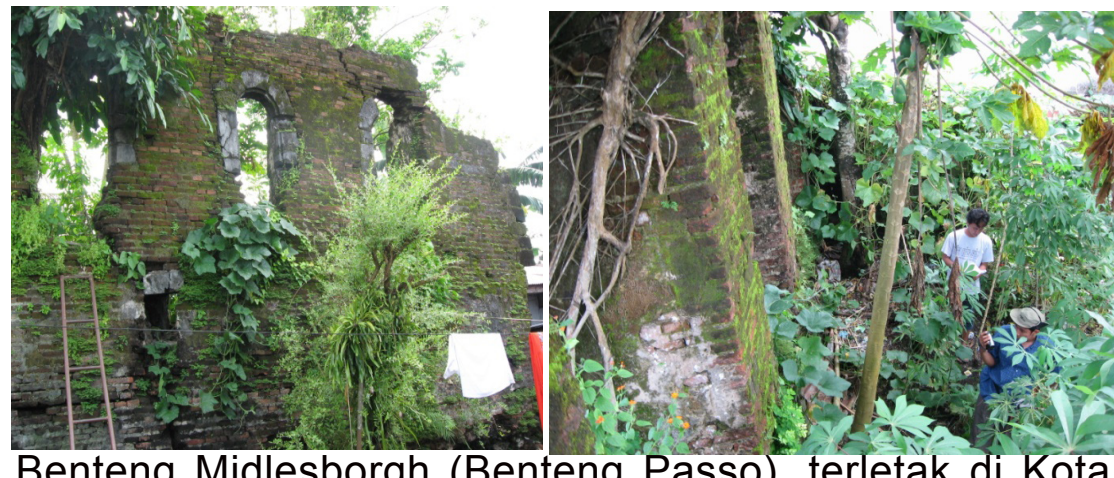

Benteng Midlesborgh (Benteng Passo), terletak di Kota Ambon, saat ini berada diantara kepungan permukiman penduduk kota Ambon. Tampak penulis dan Surveyor PDA,

1 Pemanfaatan Ruang Kawasan Lindung, pasal 26 poin e disebutkan Melestarikan cagar budaya yang berisikan benda-benda bersejarah peninggalan masa lalu, dan/atau segenap adat istiadat, kebiasaan dan tradisi setempat, serta unsur alam lainnya yang unik. Sementara itu dalam peraturan pemerintah republik indonesia (pp) Nomor 47 tahun 1997 (47/1997) tentang rencana tata ruang wilayah nasional, menyangkut pola pemanfataan ruang disebutkan bahwa Kawasan cagar budaya sebagaimana dimaksud pada ayat (1) huruf e tidak terbagi lagi dalam kawasan yang lebih kecil. Berdasarkan Raperpres dan Peraturan pemerintah itu, maka kawasan benteng Kolonial dapat dikategorikan sebagai kawasan Cagar Budaya. Di wilayah Maluku pe nge mbangan

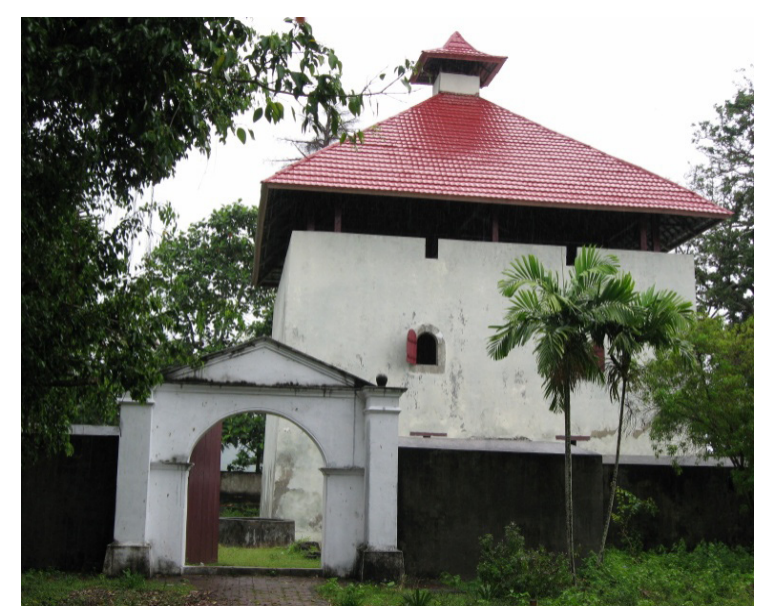

Benteng Amsterdam di Desa Hila Kecamatan Leihitu (jazirah Leihitu) Kabupaten Maluku Tengah. Secara geografis masih berada di Pulau Ambon. 
kawasan cagar Budaya dapat dikaitkan dengan pengembagan rencana tata ruang wilayah maupun kota, mengingat kawasan benteng Kolonia terdapat di hampir seluruh wilayah Maluku yang pada umumnya terdapat di wilayah kota.

Kawasan kota lama biasanya merupakan kawasan bersejarah atau heritage district yaitu kawasan yang banyak memiliki bangunan dengan keunikan. Kawasan kota lama dengan keunikan tersebut telah menjadi Identitas Kota atau landmark. Benteng dalam konteks tata ruang kota di Indonesia memegang peranan penting. Bahkan ada dugaan bahwa beberapa kota di Indonesia menjadi tumbuh dan berkembang dengan bangunan benteng sebagai sentralnya (Marihandono, 2008). Demikian pula di wilayah Maluku, Ternate, Ambon, Banda, Saparua dan lain-lain merupakan wajah kota lama yang terus berkembang sebagai kelanjutan dari embrium kota dengan citra kolonial yang sangat lekat.

Mumford (1967), mengungkapkan bahwa perkembangan kota sangat berkaitan dengan fungsi waktu, hal mi mengingatkan kita bahwa kota sekarang pembentukannya didasarkan pada masa lampau. Dengan demikian aspek historis memegang peran yang sangat penting dalam "membentuk" morfologi kota (Mumford, 1967). Sebagai urban artifact, kota dalam perjalanan sejarahnya telah dan akan terus membentuk suatu pola morfologi sebagai implementasi bentuk perubahan sosial-budaya masyarakat yang membentuknya. Pola morfologi kota merupakan kesatuan organik elemen-elemen pembentuk kota, yang mencakup; elemen detail (bangunan, sistem sirkulasi, open space dan prasarana kota), aspek tata bentuk kota town scape (pola tata ruang, komposisi lingkungan terbangun terhadap pola bentuk di sekitar kawasan), serta aspek peraturan (totalitas rencana yang memperihatkan dinamika kawasan kota). Dalam kegiatan perencanaan kota, penekanan awal yang dilakukan lebih banyak pada aspek lingkungan fisik dan ekologis kota. Kegiatan perencanaan kota tidaklah sebatas aspek fisik tetapi memuat didalamnya aspek sosialekonomi dan sosial-budaya.(Pawitro, 2003).

Proses revitalisasi sebuah kawasan atau bagian kota mencakup perbaikan aspek fisik dan aspek ekonomi dari bangunan maupun ruang kota. Revitalisasi fisik merupakan strategi jangka pendek yang dimaksudkan untuk mendorong terjadinya peningkatan kegiatan ekonomi jangka panjang. Revitalisasi fisik diyakini dapat meningkatkan kondisi fisik (termasuk ju-a ruang-ruang publik) kota, namun tidak untuk jangka panjang. Untuk itu, tetap diperlukan perbaikan dan peningkatan aktivitas ekonomi (economic revitalization) yang merujuk kepada aspek sosial-budaya serta aspek lingkungan (environmental objectives). Hal tersebut mutlak diperlukan karena melalui pemanfaatan yang produktif, diharapkan akan terbentuklah sebuah mekanisme perawatan dan kontrol yang langgeng terhadap keberadaan fasilitas dan infrastruktur kota (Wongso, 2001).

Penataan dan Revitalisasi Kawasan menurut Departemen Kimpraswil (2002) adalah rangkaian upaya menghidupkan kembali kawasan yang cenderuang mati, meningkatkan nilai-nilai vitalitas yang strategis dan signifikan dari kawasan yang masih mempunyai potens dan atau mengendalikan kawasan yang cenderung kacau atau semrawut. Penataan dan Revitalisasi Kawasan dilakukan melalui pengembangan kawasan-kawasan tertentu yang layak untuk direvitalisasi baik dari segi setting kawasan (bangunan dan ruang kawasan), kualitas lingkungan, sarana, prasarana dan utilitas kawasan, sosio kultural, sosio ekonomi dan sosio politik

Revitalisasi pada prinsipya tidak sekedar menyangkut masalah konservasi bangunan dan ruang kawasan bersejarah saja, tetapi lebih kepada upaya untuk mengembalikan atau menghidupkan kembali kawasan dalam konteks kota yang tidak berfungsi atau menurun fungsinya agar berfungsi kembali, atau menata dan mengembangkan lebih lanjut kawasan yang berkembang sangat pesat namun kondisinya cenderung tidak terkendali.

Hilangnya vitalitas awal dalam suatu kawasan historis budaya umumnya ditandai dengan kurang terkendalinya perkembangan dan pembangunan kawasan, sehingga mengakibatkan terjadinya kehancuran kawasan, baik secara self destruction maupun creative destruction (Danisworo, 2000). Revitalisasi merupakan sebuah program berkelanjutan mulai tahap-tahap jangka pendek hingga jangka panjang, mulai dari ruang yang kecil hingga meluas. Revitalisasi terkait dengan upaya membangun dan menggalang kekuatan masyarakat loka membentuk denyut kehidupan yang sehat yang mampu memberikan keuntungan sosial-budaya dan ekonomi bagi masyarakatnya. Revitalisasi adalah upaya untuk memvitalkan kembali suatu kawasan atau bagian kota yang dulunya pernah vital atau hidup, akan tetapi kemudian mengalami penurunan/degradasi baik secara fisik, ekonomi dan sosial budaya Pendekatan revitalisasi harus mampu mengenali dan memanfaatkan potensi lingkungan (sejarah, makna, keunikan lokasi dan citra tempat). 
Revitalisasi bukan hanya berorientasi pada keindahan fisik saja tapi juga harus mampu meningkatkan stabilitas lingkungan, pertumbuhan perekonomian masyarakat, pelestarian dan pengenalan budaya (Ichwan, 2004)

Menurut Daniworo (2000) dan Martokusumo (2008), program revitalisasi setidaknya mencakup beberapa tahapan subtansial yakni :

\section{A. Intervensi fisik}

Intervensi fisik mengawali kegiatan fisik revitalisasi dan dilakukan secara bertahap, meliputi perbaikan dan peningkatan kualitas dan kondisi fisik bangunan, tata hijau, sistem penghubung, system tanda/ reklame dan ruang terbuka kawasan (urban realm). Mengingat citra kawasan sangat erat kaitannya dengan kondisi visual kawasan, khususnya dalam menarik kegiatan dan pengunjung, intervensi fisik ini perlu dilakukan. Isu lingkungan (environmental sustainability) pun menjadi penting, sehingga intervensi fisik pun sudah semestinya memperhatikan konteks lingkungan. Perencanaan fisik tetap harus dilandasi pemikiran jangka panjang.

\section{A. Rehabilitasi ekonomi}

Revitalisasi yang diawali dengan proses peremajaan artefak urban harus mendukung proses rehabilitasi kegiatan ekonomi. Perbaikan fisik kawasan yang bersifat jangka pendek, diharapkan bisa mengakomodas kegiatan ekonomi informal dan formal (local economic development), sehingga mampu memberikan nilai tambah bagi kawasan kota (P. Hall/U. Pfeiffer, 2001). Dalam konteks revitalisasi perlu dikembangkan fungsi campuran yang bisa mendorong terjadinya aktivitas ekonomi dan sosial (vitalitas baru)

\section{B. Revitalisasi sosial / institusional}

Keberhasilan revitalisasi sebuah kawasan akan terukur bila mampu menciptakan lingkungan yang menarik (interesting), jadi bukan sekedar membuat beautiful place. Maksudnya, kegiatan tersebut harus berdampak positif serta dapat meningkatkan dinamika dan kehidupan sosial masyarakat/warga (public realms). Sudah menjadi sebuah tuntutan yang logis, bahwa kegiatan perancangan dan pembangunan kota untuk menciptakan lingkungan sosial yang berjati diri (place making) dan hal ini pun selanjutnya perlu didukung oleh suatu pengembangan institusi yang baik. (Danisworo, 2000; Martokusumo; 2007)
Oleh karena itu di Wilayah Maluku, kegiatan revitalisasi kawasan benteng-benteng kolonial sebagai contoh revitalisasi kawasan Banda Neira sebagai pusat wisata warisan budaya, setidaknya harus bisa menyelesaikan dua isu (masalah) pokok, yakni revitalisasi sumberdaya arkeologi, sekaligus pemulihan (recovery) sosial dan ekonomi masyarakat. Dengan demikian program revitalisasi setidaknya juga mencakup penataan kawasan. Penataan kawasan sangat penting dilakukan mengingat hasil survei Pusat Dokumentasi Arsitektur (2007) memperoleh data bahwa disekitar obyek Benda Cagar Budaya (BCB) terdapat fasilitas umum dan sosial baik berupa perumahan (permukiman) penduduk, perkantoran, pendidikan dan fasilitas umum lainnya. Selain itu pada umumnya kondisi kawasan di Banda Neira meliputi dua kategori yakni, tidak berkembang dan sedang berkembang. Oleh karena itu penataan kawasan patut mempertimbangkan kondisi tersebut (Handoko, 2008). Program penting lainnya adalah Zonasi (Pemintakatan). Mundarjito (2006) menjelaskan zonasi bertujuan menjaga, melindungi, memastikan dan mempertahankan suasana historis. Kondisi lingkungan sejarah pada dasarnya tersusun secara harmonis dari bangunan purbakala dan sejarah, situs dan lingkungan alam sekitar, serta gaya hidup dan sikap penduduknya (Mundarjito, 2006 :8). Penentuan batas lahan yang akan dikelola sebagai taman harus dilandasi oleh metode ilmiah yang disebut dengan pemintakatan (Zonasi). Zoning merupakan suatu cara atau teknik yang kuat dan fleksibel untuk mengontrol pemanfaatan lahan pada masa mendatang. Pernyataan tersebut menekankan pada pengaturan dan pengendalian pemanfaatan lahan untuk berbagai jenis kepentingan yang diatur secara bersamaan, sementara dalam pemintakatan arkeologi tujuan utamanya adalah menentukan wilayah situs serta mengatur atau mengendalikan setiap kegiatan yang dapat dilakukan dalam wilayah yang telah ditetapkan (Callcott, 1989: 38)

Menurut Soemarwoto (1987) tujuan zoning adalah untuk menghindari konflik antar kepentingan yang terkait di dalamnya. Penentuan batas zonasi didasarkan pada batas asli situs, batas geotopografis maupun batas kelayakan pandang (Abriter), (Prasetya dan Hartono 1997, hal 8-9). Penentuan batas zonasi ini sejalan dengan Peraturan Perundang-undangan Republik Indonesia Tentang Benda Cagar Budaya, bab IV pasal 23 (2) yang menyebutkan bahwa:"Untuk kepentingan perlindungan benda cagar budaya dan situs diatur batas-batas situs dan lingkungannya sesuai dengan kebutuhan". Zonasi kawasan 
Benteng Kolonial BCB di Kepulauan Maluku terutama diterapkan pada tiap-tiap kawasan yang memiliki masterpiece, misalnya benteng Victoria di Kota Ambon, Benteng Belgica dan Nassau di Banda Neira, Benteng Horn di Pulau Haruku, Benteng Duurstede di Pulau Saparua dan sebagainya.

Kasnowiharjo (2001) menjelaskan keberadaan tinggalan arkeologi menjadi kurang berarti jika tidak ditunjang dengan fasilitasfasilitas pendukung lainnya. Pengalihan fungsi bangunan-bangunan tua menjadi bangunan fasilitas umum dapat dilakukan sepanjang tidak mengalami perubahan bentuk dan sebelumnya dilakukan studi kelayakan terhadap bangunan tersebut. Selain itu di wilayah obyek-obyek wisata budaya selayaknya dilakukan pemintakatan menjadi beberapa mintakat, yaitu mintakat inti, penyangga dan pengembang. Mintakat inti adalah tinggalan arkeologi itu sendiri yang merupakan obyek utama dari tujuan wisata, mintakat penyangga merupakan wilayah di sekeliling situs yang berfungsi untuk menekan konsentrasi arus pengunjung ke zona inti sehingga kelestarian situs tetap terjaga, serta mintakat pengembangan merupakan lahan fasilitas yang sebagian besar arealnya digunakan untuk pembangunan prasarana dan sarana pengunjung (Kasnowihardjo 2001: 19)

Pada umumnya pola penataan ruang, lebih mengacu pada pola penataan ruang di

Eropah, yakni dengan pola pemintakatan atau zoning yang ketat. Dalam pelaksanaannya produk penataan ruang pola zoning tidak efektif, sehingga terbit Instruksi Menteri Dalam Negeri No.: 30 tahun 1985 tentang Penegakan Hukum/ Peraturan Dalam Rangka Pengelolaan
Daerah Perkotaan, yang diikuti dengan terbitnya: (a) Peraturan Menteri Dalam Negeri Nomor 7 tahun 1986 tentang Penetapan Batas Wilayah Kota di Seluruh Indonesia, dan (b) Peraturan Menteri Dalam Negeri Nomor: 2 tahun 1987 tentang Pedoman Penyusunan Rencana Kota. Kedua peraturan Menteri Dalam Negeri tersebut merupakan acuan para pihak terlibat dalam penyusunan tata ruang kota, sebelum ditetapkannya Peraturan Pemerintah tentang Pelaksanaan Undang-Undang Penataan Ruang. (Sunardi, 2004).

Secara konseptual, revitalisasi merupakan usaha meningkatkan vitalitas kawasan kota melalui peningkatan kualitas lingkungan, dengan mempertimbangkan aspek sosial budaya dan karakteristik/kekhususan kawasan. Fokus dari revitalisasi sendiri adalah upaya untuk menumbuhkan pengembangan ekonomi kawasan, sehingga upaya memberdayakan, merawat dan memperkuat karakater kawasan dapat berlangsung dengan baik. Hal ini dapat berarti menghidupkan kembali aktifitas/kegiatan yang pernah ada atau secara lebih kompleks merestrukturisasi aktifitas ekonomi kawasan (Tiesdell et al., 1996 dalam Martokusumo, 2007). Dengan demikian program revitalisasi sesungguhnya berdasarkan atau menyesuaikan dengan potensi lingkungan dan sumberdaya yang ada Potensi lingkungan menyangkut baik fisik alam dan bentanglahan, sejarah lokalitas, tradisi, makna dan citra kawasan itu sendiri.

Proses revitalisasi sebuah kawasan atau bagian kota mencakup perbaikan aspek fisik, aspek sosial/budaya serta aspek ekonomi dari bangunan maupun ruang kota. Revitalisasi fisik merupakan strategi jangka pendek yang dimaksudkan untuk menciptakan keadaan yang kondusif untuk mendorong terjadinya peningkatan kegiatan ekonomi jangka panjang. Rehabilitasi ekonomi yang merujuk kepada aspek sosialbudaya serta pertimbangan lingkungan (environmental concerns) mutlak diperlukan, karena hanya dengan melalui pemanfaatan produktif, maka terwujudlah sebuah bentuk mekanisme 'perawatan' dan kontrol terhadap kelangsungan fasilitas dan infrastruktur kota. Artinya pemanfaatan produktif dari aset perkotaan secara tidak langsung akan menjadi sumber daya bagi upaya pemeliharaan dari aset publik tersebut. Merujuk kepada konsep keterkaitan, konservasi/pelestarian lebih dari sekedar pekerjaan teknis seni bangunan atau seni binakota belaka, tapi menjadi upaya manusia membuat penafsiran secara kontinu terhadap karya-karya yang telah dibuatnya. Bila hal ini dikaitkan dengan kegiatan pelestarian, maka pemanfaatan bangunan tua/kawasan lama untuk mengakomodasi 
kebutuhan baru yang relevan -melalui alihfungsi- dapat dipahami sebagai upaya interpretasi baru terhadap artefak/warisan budaya (Martokusumo, 2007). Hal yang cukup relevan adalah perlu menyiapkan sumberdaya manusia, yakni masyarakat yang handal untuk menyambut program revitalisasi kawasan. Prasodjo (2004) mengatakan pemberdayaan masyarakat diperlukan agar tidak ada ketimpangan sehingga masyarakat mampu bersaing dengan perkembangan zaman dan perubahan sosial. Masyarakat lokal sebagai pumukim yang bertempat tinggal di sekitar kawasan memiliki potensi sosial, budyaa, politik, maupun ekonomis yang dapat dikembangkan sehingga akan menumbuhkan ketergantungan yang saling menguntungkan antara kawasan benteng Kolonial (kawasan BCB) dan masyarakat sekitar (Prasodjo, 2004:3).

Dengan demikian, menurut penulis maka langkah pemberdayaan masyarakat yang penting dilakukan antara lain: a). menggali permasalahan di tingkat masyarakat serta merencanakan penyelesaikan masalah berdasarkan kondisi dan potensi yang masyarakat miliki, hal ini dikaitkan menyangkut pengelolaan kawasan Benteng Kolonial dan dampak serta manfaatya bagi masyarakat. b.) Peningkatan Kapasitas Sumberdaya Manusia. Diutamakan dengan melakukan program peningkatan ketrampilan penduduk dalam menunjang kawasan benteng Kolonial. c). Pemberdayaan ekonomi, berdasarkan masalah dan kebutuhan serta kemampuan masyarakat serta nilai-nilai budaya setempat.

\section{Kesimpulan}

Wilayah kepulauan Maluku meliputi Propinsi Maluku dan maluku Utara adalah sebuah wilayah yang sangat kaya dengan kawasan-kawasan bersejarah dengan adanya deretan benteng-benteng kolonial yang merupakan citra kolonial yang sangat lekat. Keberadaan kawasan benteng Kolonial ini adalah potensi yang snagat kaya untuk pengembangan wilayah baik dalam aaspek sosial budaya maupun ekonomi. Namun kondisi kekinian menggambarkan bahwa kawasan benteng-benteng Kolonial di wilayah Maluku, keberadaannya tidak mendukung pembangunan, mengingat kondisi kawasan yang tidak tertata serta kondisi fisik benteng yang pada umumnya rusak dan tidak terpelihara. Oleh karena itu perlu dilakukan upaya-upaya strategis sebagai bagian dari program revitalisasi yakni :

1. Program revitalisasi berdasarkan atas penilaian dan pengkategorian kawasan untuk dipertimbangkan dalam skala prioritas program. Penilaian kawasan adalah dengan mengidentifikasi kondisi kawasan baik fisik maupun sosial budaya serta kondisi atau dinamika kawasan sekitar. Penilaian dan pengkategorian kawasan akan menghasilkan perangkingan atau daftar urutan proritas kawasan mana yang paling efektif dan efisien untuk dilakukan program revitalisasi. Penilaian dan poengaktegorian kawasan juga didasarkan oleh kondisi pencitraan kawasan kolonial yang masih dapat diidentifikasi baik jaringan jalan, batas-batas dan integrasi kawasan maupun landmark. Selanjutnya program revitalisasi juga dilakukan sefektif dan sefisien mungkin, oleh karena itu perlu dibuat urutan skala prioritas dengan kriteria-kriteria tertentu.

2. Program revitalisasi kawasan benteng kolonial disesuaikan dengan rencana tata ruang wilayah dan kota, sehingga keberadaan kawasan benteng kolonial merupakan kawasan cagar budaya yang termuat dalam rencana tata ruang wilayah. Keberadaan kawasan benteng Kolonial yang umumnya berada dalam kawasan kota, sehingga proses revitalisasi sebuah kawasan atau bagian kota mencakup perbaikan aspek fisik dan aspek ekonomi dari bangunan maupun ruang kota, serta mencakup pula pemberdayaan masyarakat di sekitar kawasan benteng kolonial. 


\section{DAFTAR PUSTAKA}

Danisworo, Muhammad dan Martokusumo,Widjaya 2000. Revitalisasi Kawasan Kota Sebuah Catatan dalam Pengembangan dan Pemanfaatan Kawasan Kota, www.urdi.org (urban and reginal development institute, 2000).

Dewi, Parawaty dan Surjono, Antaraiksa 2008 Pelestarian Kawasan Eks Pusat Kota Kolonial Lama Semarang. Arsitektur e-Journal, Volume 1 Nomor 3, November 2008

Eriza Faizal, 2009 Arahan Konsep Perancangan Kawasan Konservasi Benteng Marlborough Kota Bengkulu. Tugas Akhir. Jurusan Perencanaan Wilayah dan Kota Fakultas teknik Universitas diponegoro. Semarang

Handoko, Wuri 2008 Revitalisasi Banda Neira Pasca Konflik. Kumpulan Makalah. Pertemuan Ilmiah Arkeologi (PIA) XI. Jakarta. Ikatan Ahli Arkeologi Indonesia.

Ichwan, Matari Rido 2004 Penataan dan Revitalisasi Sebagai Upaya Meningkatkan Daya Dukung Kawasan Perkotaan. Sekolah Pasca Sarjana. Institut Pertanian Bogor.

Indrawaty, Yanthi Lydia 2008 Peran serta Stakeholder Dalam Revitalisasi Kawasan Keraton Kasunanan Surakarta.Tugas Akhir. Jurusan Perencanaan Wilayah dan Kota. Fakultas Teknik Universitas Diponegoro. Semarang

Kasnowiharjo, H Gunadi, 2001, Manajemen Sumberdaya Arkeologi, Lembaga Penerbit Universitas Hasanudin, Makasar

Kimpraswil, 2002. Pedoman Umum Program Penataan dan Revitalisasi Kawasan, Departemen Permukiman dan Prasarana Wilayah Direktorat Jenderal Tata Perkotaan dan Tata Perdesaan, Jakarta.

Kwanda, Timoticin 2004 Potensi Dan Masalah Kota Bawah Surabaya Sebagai Kawasan Pusaka Budaya. The 1st International Urban Conference, August 23rd-25th, 2004. Surabaya.
Mansyur, Syahruddin 2008 Inventarisasi dan Identifikasi Benteng Kolonial di Propinsi Maluku.Kumpulan Makalah. Pertemuan Ilmiah Arkeologi (PIA) XI. Jakarta. Ikatan Ahli Arkeologi Indonesia.

Marihandono, Djoko 2008 Perubahan Peran dan Fungsi Benteng dalam Tata Ruang Kota. Wacana. Vol. 10 No. 1, April 2008

Martokusumo, Dr. Ing, Ir. 2007 Mendaur Ulang Kota Tambang Sawahlunto. Beberapa Catatan tentang pendekatan Konservasi 